\title{
Primaquine decreased plasma concentration of ritonavir: single- and repeated-dose study in Sprague Dawley rats
}

\author{
Melva Louisa, Vivian Soetikno, Nafrialdi, Rianto Setiabudy, Frans D. Suyatna \\ Department of Pharmacology and Therapeutics, Faculty of Medicine, Universitas Indonesia, Jakarta, Indonesia
}

\begin{abstract}
Abstrak
Latar belakang: Penelitian ini dilakukan untuk meneliti pengaruh pemberian ritonavir dan primakuin bersamaan, yang diberikan dalam dosis tunggal atau dosis berulang pada konsentrasi plasma ritonavir pada tikus.

Metode: Pada studi dengan pemberian dosis tunggal, 30 tikus Sprague Dawley jantan secara acak diberikan ritonavir 20 $\mathrm{mg} / \mathrm{kgBB}$ atau ritonavir $20 \mathrm{mg} / \mathrm{kgBB}+$ primakuin $1,2 \mathrm{mg} / \mathrm{kgBB}$ atau ritonavir $20 \mathrm{mg} / \mathrm{kgBB}+$ ketokonazol $10 \mathrm{mg} / \mathrm{kgBB}$. Ketokonazol digunakan sebagai kontrol positif penghambat metabolisme ritonavir. Pada studi dengan pemberian dosis berulang, 30 tikus Spraque Dawley secara acak diberikan ritonavir $20 \mathrm{mg} / \mathrm{kgBB} / \mathrm{hari}$ atau ritonavir $20 \mathrm{mg} / \mathrm{kgBB} / \mathrm{hari}$ + primaquine 1,2 mg/kgBB/hari atau ritonavir $20 \mathrm{mg} / \mathrm{kgBB} / \mathrm{hari}+$ rifampisin $100 \mathrm{mg} / \mathrm{kgBB} /$ day. Rifampisin digunakan sebagai kontrol positif penginduksi metabolisme ritonavir.
\end{abstract}

Hasil: Pada pemberian dosis tunggal, ketokonazol meningkatkan area dibawah kurva kadar plasma (AUC) ritonavir $(\uparrow 114,8 \%, p<0.05)$, sedangkan primakuin cenderung menurunkan AUC ritonavir ( $\downarrow 32,6 \%, p>0.05)$. Pemberian dosis berulang menunjukkan bahwa rifampisin menurunkan AUC ritonavir $(\downarrow 42,8 \%, p<0.001)$, dan primakuin menurunkan AUC ritonavir $(\downarrow 46,6 \%, p<0.001)$.

Kesimpulan: Pemberian primakuin dan ritonavir bersamaan dapat menurunkan AUC ritonavir. Hal ini dapat menyebabkan konsentrasi ritonavir sebagai anti-HIV tidak mencukupi, sehingga dapat menyebabkan kegagalan terapi dengan ritonavir. (Med J Indones 2011; 20:190-4)

\begin{abstract}
Background: The present study was aimed to explore the effects of ritonavir and primaquine combination given as a singledose or repeated-dose compared to ritonavir alone on ritonavir plasma concentration in the rats.

Methods: In single-dose study, 30 male Spraque Dawley rats were randomly allocated to receive ritonavir $20 \mathrm{mg} / \mathrm{kg} \mathrm{BW}$ or ritonavir $20 \mathrm{mg} / \mathrm{kg} \mathrm{BW}+$ primaquine $1.2 \mathrm{mg} / \mathrm{kg} \mathrm{BW}$ or ritonavir $20 \mathrm{mg} / \mathrm{kg} \mathrm{BW}+$ ketokonazole $10 \mathrm{mg} / \mathrm{kg} \mathrm{BW}$. Ketokonazole was used as positive control of ritonavir metabolism inhibitor. In the repeated-dose study, thirty Spraque Dawley male rats were randomly allocated to receive ritonavir $20 \mathrm{mg} / \mathrm{kg} \mathrm{BW} /$ day or ritonavir $20 \mathrm{mg} / \mathrm{kg} \mathrm{BW} /$ day + primaquine $1.2 \mathrm{mg} / \mathrm{kg} \mathrm{BW} /$ day or ritonavir $20 \mathrm{mg} / \mathrm{kg} \mathrm{BW} /$ day + rifampicin $100 \mathrm{mg} / \mathrm{kg} \mathrm{BW} /$ day. Rifampicin was used as a positive control of ritonavir metabolism inducer.
\end{abstract}

Results: In the single-dose study, ketokonazole increased the area under the plasma concentration (AUC) of ritonavir ( $\uparrow$ $114.8 \%, p<0.05)$, while primaquine tended to decrease the AUC of ritonavir $(\downarrow 32.6 \%, p>0.05)$. Repeated-dose study showed that rifampicin decreases the AUC of ritonavir $(\downarrow 42.8 \%, \mathrm{p}<0.001)$, and primaquine decreased the AUC of ritonavir plasma concentration $(\downarrow 46.6 \%, \mathrm{p}<0.001)$.

Conclusion: Concomitant administration of primaquine and ritonavir decreases the AUC of ritonavir. This effect may result in the insufficient concentration of ritonavir as anti-HIV, which may lead to treatment failure with ritonavir. (Med J Indones 2011; 20:190-4)

Key words: drug interaction, metabolism, primaquine, ritonavir

Concomitant use of antimalaria and anti-HIV is a new challenge in the management of co-infection of malaria/ HIV. Drug interaction should be considered for treatment success. Anti-HIV regimen consists of 3 to 4 drugs. If an HIV patient has to take malaria treatments, then the patient receives two or three additional drugs. ${ }^{1,2}$

Interaction between antimalarial and antiretroviral drugs mostly involves anti-HIV drugs protease inhibitors (PIs) and non nucleotide reverse transcriptase inhibitors (NNRTIs). Protease inhibitors such as ritonavir are known to inhibit cytochrome P450 enzymes (CYPs), while NNRTIs may act as inhibitor or inducer of
CYP. ${ }^{1}$ CYPs are the main enzyme system in the liver responsible for drug metabolism of nearly $80 \%$ of currently known drugs. ${ }^{3}$

Primaquine is used for radical treatment of malaria caused by Plasmodium vivax. Plasmodium vivax is one of the parasites, which causes human malaria in the subtropics. ${ }^{4}$ Primaquine is the only drug available to eliminate hypnozoites of P.vivax. ${ }^{4,5}$ Administration of 14-day course of primaquine is the recommended regimen that can eliminate the hypnozoites in the liver. ${ }^{5}$ The administration of primaquine in a relatively long period for treatment is unavoidable in endemic areas. ${ }^{6}$ 
There are no data showing the exact metabolism pathway of primaquine in human. In an in vitro study, it was shown that primaquine was a substrate of cytochrome P450 3A4 (CYP3A4), ${ }^{7}$ while ritonavir is known as substrate and inhibitor of CYP3A4. ${ }^{8}$ Interaction study between primaquine and ritonavir has never been done before. ${ }^{1,9} \mathrm{We}$ supposed that primaquine has an inhibiting or otherwise inducing properties on the metabolism of ritonavir. Inhibition of ritonavir metabolism by primaquine can cause an increase in serum drug concentration and risk of drug intoxication, while induction of ritonavir metabolism by primaquine can decrease serum drug concentration, and cause treatment failure and drug resistance.

The aim of the study was to test whether primaquine had an inhibiting or otherwise an inducing effect on the metabolism of ritonavir.

\section{METHODS}

The study protocol was approved by the Ethics Committee of the Faculty of Medicine, Universitas Indonesia. This study was conducted in the Department of Pharmacology and Therapeutics, Faculty of Medicine, Universitas Indonesia from November 2009 through April 2010.

\section{Experimental design}

The study consisted of two parts. The first part was designed to investigate whether primaquine had an inhibitory effect on the metabolism of ritonavir, and was given concomitantly as a single dose. Ketokonazole was used as a positive control of ritonavir metabolism inhibitor. Thirty male Spraque Dawley rats weighing \pm $300 \mathrm{~g}$ were randomly allocated into 3 groups of 10 rats to receive either ritonavir $20 \mathrm{mg} / \mathrm{kg} \mathrm{BW}$, or ritonavir 20 $\mathrm{mg} / \mathrm{kg} \mathrm{BW}+$ primaquine $1.2 \mathrm{mg} / \mathrm{kg} \mathrm{BW}$, or ritonavir 20 $\mathrm{mg} / \mathrm{kg} \mathrm{BW}+$ ketokonazole $10 \mathrm{mg} / \mathrm{kg} \mathrm{BW}$, orally.

The second part was carried out to investigate whether primaquine had an inducing effect on the metabolism of ritonavir, and was given concomitantly in a repeated fashion for 5 days. Rifampicin was used as a positive control of ritonavir metabolism inducer. Thirty male Spraque Dawley rats weighing $\pm 300 \mathrm{~g}$ were randomly allocated into 3 groups of 10 rats to receive either ritonavir $20 \mathrm{mg} / \mathrm{kg} \mathrm{BW} /$ day, or ritonavir $20 \mathrm{mg} / \mathrm{kg} \mathrm{BW} /$ day + primaquine $1.2 \mathrm{mg} / \mathrm{kg}$ $\mathrm{BW} /$ day, or ritonavir $20 \mathrm{mg} / \mathrm{kg} \mathrm{BW} /$ day + rifampicin 100 $\mathrm{mg} / \mathrm{kg} \mathrm{BW} /$ day, given orally, once daily.

\section{Sample collection}

In the single-dose study, serial blood samples were collected at $0,1,2,3,4$ and 6 hour/s after drug administration, while in repeated-dose study, serial blood samples were collected at day 0 (before drug administration), 1, 2, 3, 4 and 5. Blood samples were centrifuged at $3000 \mathrm{~g}$ for 15 minutes at $4^{\circ} \mathrm{C}$ and the separated sera were assayed for plasma ritonavir concentrations on the same day.

\section{HPLC method to determine ritonavir plasma concentration}

The concentration of ritonavir in plasma was measured using a validated HPLC method with ultraviolet detector at $\lambda=245 \mathrm{~nm}$. The mobile phase was methanol: acetonitrile: $\mathrm{H}_{2} \mathrm{O}=70: 15: 15$, pumped isocratically at a flow rate of $1.0 \mathrm{~mL} / \mathrm{min}$ at $35^{\circ} \mathrm{C}$. We used nevirapine as internal standard. Retention time of ritonavir and nevirapine were at 2.3 and $1.8 \mathrm{~min}$, respectively (Figure 1). Primaquine could not be detected in this system.

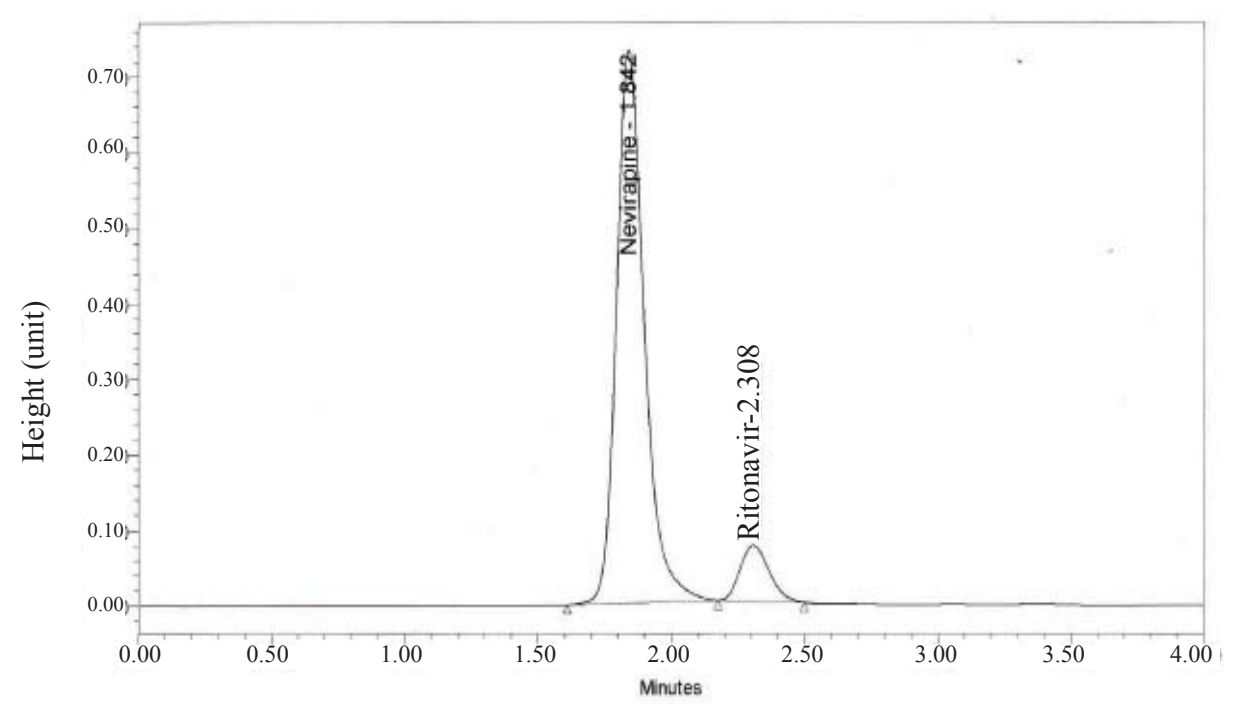

Figure 1. Chromatogram of ritonavir and nevirapine 


\section{Sample extraction and ritonavir concentration determination}

Plasma sample $(0.25 \mathrm{~mL})$ was mixed with $50 \mu \mathrm{L}$ nevirapine (internal standard) and $50 \mu \mathrm{L} \mathrm{NaOH} 0.1$ $\mathrm{N}$. The mixture was vortexed for 30 seconds before adding $1.5 \mathrm{~mL}$ of diethyl ether. Then, the sample was centrifuged at $3000 \mathrm{rpm}$ for 5 minutes. The organic layer was evaporated under a gentle stream of nitrogen. The residue was reconstituted in $200 \mu \mathrm{L}$ of mobile phase and an aliquot of $20 \mu \mathrm{L}$ was injected to the HPLC system $\left(\right.$ Waters ${ }^{\mathrm{TM}}$ ). The mixture was separated and the concentration determined on a Reverse Phase C18 Column (Symmetry ${ }^{\mathrm{TM}}$ C18 $5 \mu \mathrm{m} ; 2.6$ x $150 \mathrm{~mm}$ ).

\section{Analytical system validation}

Analytical system validation was done and the result showed that the calibration curve was linear $(r=0.9999$, $n=6$ ) in the range of $0.05-1.6 \mu \mathrm{g} / \mathrm{mL}$, and the limit of quantitation was $0.1 \mu \mathrm{g} / \mathrm{mL}$. Precision, expressed as the intra $(n=10)$ and inter-day $(n=5)$ coefficient of variation, was $\leq 5.55 \%$ on the same day and $\leq 7.34 \%$ between days for each quality control sample of $1.5 ; 3$ and $14 \mu \mathrm{g} / \mathrm{mL}$, respectively. Accuracy expressed as the intra- and inter-day $\%$ bias was $-1.1-8 \%$ on the same day and $-2.01-11.4 \%$ between days at each quality control sample.

\section{Statistical analysis}

AUC of ritonavir was calculated using the trapezoidal rule based on plasma concentrations obtained at the predetermined sampling time points as stated in methods. $\mathrm{AUC}_{0-\mathrm{t}(\mathrm{h})}$ of ritonavir concentration were analyzed using the related one-way ANOVA followed by Tukey method for multiple comparisons at a

A

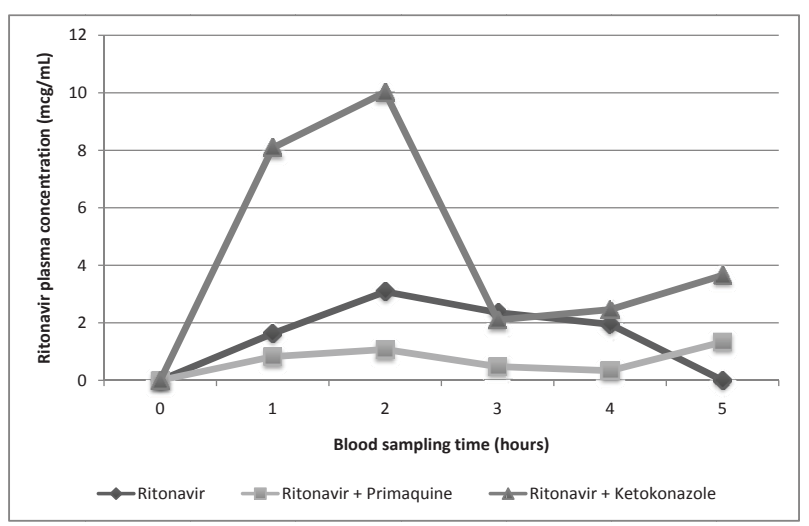

significance level of $\alpha=0.05$, when the data showed a normal and homogenous distribution. The difference of the $\mathrm{AUC}_{0-\mathrm{t}(\mathrm{h})}$ of ritonavir in plasma in concomitant treatment are expressed in \% versus ritonavir alone.

\section{RESULTS}

The mean concentration of ritonavir $( \pm \mathrm{SD})$ in a single dose study and repeated dose study versus time is shown at Figure 2. In the single dose study, as a positive control for inhibitory study, concomitant administration of ritonavir with ketokonazole clearly showed an increase in the area under the plasma concentration (AUC) of ritonavir compared to ritonavir alone (increased by $114.8 \%, \mathrm{p}<0.05)$, as expected. Ketokonazole is the known inhibitor of CYP3A4, an enzyme which also metabolizes ritonavir. Direct inhibition of metabolizing enzyme caused an increase in the plasma concentration of ritonavir. On the other hand, the administration of primaquine + ritonavir lowered the AUC of ritonavir (decreased by $32.6 \%, \mathrm{p}>0.05$ ) compared to ritonavir alone, but the decrease was not significantly different.

The result of the repeated dose study, concomitant administration of ritonavir with rifampicin clearly showed a decrease in the AUC of ritonavir (decreased by $42.8 \%, \mathrm{p}<0.001)$. This result was also expected. Rifampicin is the known inducer of cytochrome P450, not only the CYP3A4 but also several other cytochrome P450 isozymes. It was known from previous publications that the induction of cytochrome P450 in the rats might occur 3 - 5 days after drug exposure. ${ }^{10,11}$ Concomitant administration of primaquine with ritonavir given repeatedly for 5 days also lowered the AUC of ritonavir (decreased by $46.6 \%, \mathrm{p}<0.001$ ).

\section{B}

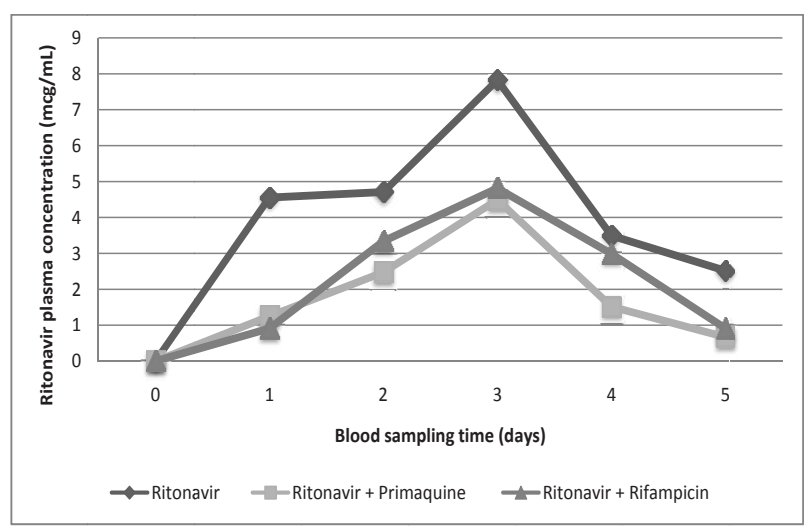

Figure 2. Mean of ritonavir concentration versus blood sampling time after: A. Single dose administration, B. Repeated dose administration for 5-days.

Single dose administration of ritonavir and primaquine resulted in the decrease of ritonavir plasma concentrations, while ritonavir and ketokonazole as positive control increased ritonavir plasma concentrations (Fig $2 \mathrm{~A}$ ). Repeated dose administration of ritonavir and primaquine resulted in the decrease of ritonavir plasma concentrations, as did the positive control (ritonavir and rifampicin) (Fig 2B). 


\section{DISCUSSION}

This study was conducted to test whether primaquine has an inhibiting or otherwise inducing effect on the metabolism of ritonavir. Most of inhibition of drug metabolism occur due to direct disruption of enzyme activity. On that account, we do a single-dose concomitant treatment to test the possibility of inhibiting effect of primaquine on the metabolism of ritonavir. Repeated dose study was done to investigate whether primaquine might have inducing effect on the metabolism of ritonavir. Xenobiotics can influence the extent of drug metabolism by activating transcription and inducing the expression of genes encoding drug metabolizing enzymes. Thus, a drug might induce the metabolism of other drugs after a certain amount of time and dose administered. ${ }^{12}$

The present study shows that single concomitant administration of ritonavir and ketokonazole results in the significant increase of ritonavir plasma concentration, while primaquine slightly reduces plasma concentration of ritonavir. Interaction between ritonavir and ketokonazole was as expected before. Ketokonazole clearly increased plasma concentration of ritonavir through its inhibitory mechanism to CYP3A4. Ketokonazole is commonly utilized as an index inhibitor of human CYP3A4 isoforms. ${ }^{13}$ Earlier research by Lim et al. 2009, showed that inhibition of CYP3A4 by ketokonazole was mediated by the disruption of pregnane $\mathrm{X}$ receptor, steroid receptor coactivator-1, and hepatocyte nuclear factor 4 [alpha] interaction. ${ }^{14}$

However, single concomitant administration of ritonavir and primaquine did not elevate the area under the plasma concentration of ritonavir. So, it is suggested that primaquine did not have inhibitory properties to CYP3A4 like that of ketokonazole. Altough not significant, primaquine reduced plasma concentration of ritonavir. We supposed that this interaction occured in the absorption stage.

Drug-drug interactions that lead to altered drug absorption can influence the rate and/or the extent of absorption. Interactions affecting absorption can result from either the formation of insoluble complexes, changes to gastric $\mathrm{pH} /$ gastrointestinal motility or drug interaction via transport protein in the intestine. ${ }^{9}$ Primaquine is a weak base. ${ }^{15}$ At the dose that we use in this study, (1.2 mg/kgBB), it is unlikely for primaquine to affect gastric $\mathrm{pH}$ and alter ritonavir absorption through this mechanism. The most plausible explanation of this decrease might be through the interaction via transport protein in the intestine. It is known that both ritonavir and primaquine is a substrate of P-glycoprotein, an efflux transporter that is widely expressed in the apical side of the intestinal epithelia. ${ }^{16,17}$ However, no study has ever confirmed the interaction of ritonavir and primaquine via P-glycoprotein before.

Our result showed that repeated-dose concomitant administration of ritonavir with rifampicin significantly decreased the AUC of ritonavir, in accordance to concomitant administration of ritonavir with primaquine that consistently lowered the AUC of ritonavir. It is widely known that rifampicin is an inducer of cytochrome P450, not only of CYP3A4 isoform, but also inducer of CYP2Cs and CYP2Bs. Among those CYPs isoforms, CYP3As are more efficiently induced by rifampicin. ${ }^{10}$ Rifampicin induces cytochrome P450 through the activation of pregnane $\mathrm{X}$ receptor (PXR), which acts as a ligand-activated transcription factor. Thus, when rifampicin binds to PXR, it activates transcription of CYP3A4 and several other genes. ${ }^{18}$

The fact that ritonavir alone, given in repeated-dose for 5 days, did not show dose accumulation is an interesting finding. It was shown that plasma concentrations of ritonavir continued to increase from the first administration to Day 3 (Figure 2B), but then started to decline on Day 4 and Day 5. We suggested that this is due to the autoinduction (the ability to induce its own metabolism) properties of ritonavir. Aside from its inhibitory properties to CYP3A4, ritonavir is also a moderate inducer of CYP3A4. ${ }^{19}$ However, the autoinduction effect of ritonavir to CYP3A4 still needs to be confirmed.

Our results showed that both single- and repeateddose concomitant administration of ritonavir and primaquine reduced the AUC of ritonavir. The decrease was significant, and lowered ritonavir AUC by $46.6 \%$ (in repeated-dose study), which is similar to that caused by rifampicin (42.8\%). This decrease could result in the insufficient concentration of ritonavir as antiHIV, which might lead to treatment failure and drug resistance with protease inhibitor. In addition, ritonavir is widely used as agent to boost plasma concentrations of other protease inhibitors.

We propose two possible explanations for the decrease of ritonavir AUC by primaquine. Primaquine might have inducing effect to cytochrome P450 that occured through the activation of nuclear receptor. The second explanation, it might result from the cumulative decrease of ritonavir concentration that occured in the absorption site.

The exact mechanism of ritonavir and primaquine interaction can not be confirmed from the present study. Further mechanistic studies on specific drug metabolizing enzyme (CYP3A4) or drug transporters (i.e. P-glycoprotein) will provide better understanding about the particular drug interactions. 
Ourstudy used animal model to get initial information for drug interactions. The clinical application of this model is limited by species differences in patterns of metabolic biotransformation and systemic pharmacokinetics. ${ }^{20}$ Thus, our result still needs to be confirmed in clinical trials that explore full pharmacokinetic parameters of ritonavir. Furthermore, this study only showed the effect of primaquine to the AUC of ritonavir. Therefore, further research to study the effect of ritonavir on plasma concentration of primaquine is a challenge.

In conclusion, this study showed that single- or repeateddose administration of primaquine decreased plasma concentration of ritonavir in animal models. These findings may serve as an evidence-based information to conduct clinical trials in human.

\section{Acknowledgments}

This study was funded by Hibah Strategis Nasional 2009 contract number 407AC/DRPM-UI/A/N1.4/2009.

\section{REFERENCES}

1. Khoo S, Back D, Winstanley P. The potential for interactions between antimalarial and antiretroviral drugs. AIDS. 2005; 19: $995-1005$.

2. Hewitt K, Stekette R, Mwapasa V, Whitmorth J, French N. Interactions between HIV and malaria in non-pregnant adults: Evidence and implications. AIDS. 2006; 20: 1993 - 2004.

3. Venkatakrishnan K, von Moltke LL, Greenblatt DJ. Human drug metabolism and cytochromes P450: Application and relevance of in vitro models. J Clin Pharmacol. 2001; 41: $1149-79$.

4. Galappaththy GNL, Omari AAA, Tharyan P. Primaquine for preventing relapses in people with Plasmodium vivax malaria. Cochrane Database of Systematic Reviews. 2007; Issue 1; Art. No. CD004389.

5. Direktorat Jenderal Pengendalian Penyakit dan Penyehatan Lingkungan Depkes RI. Pedoman Penatalaksanaan Kasus Malaria di Indonesia. Jakarta: Depkes RI 2008.

6. Leslie T, Mayan I, Mohammed N, Erasmus P, Kolaczinsky J, Whitty CJM, et al. A randomised trial of an eight-week, once weekly primaquine regimen to prevent relapse of Plasmodium vivax in Northwest Frontier Province, Pakistan. PLoS ONE. 2008; 3:e2861

7. Li XQ, Bjorkman A, Andersson TB, Gustafsson LL, Masimirembwa CM. Identification of human cytochrome
P450s that metabolise anti-parasitic drugs and predictions of in vivo drug hepatic clearance from in vitro data. Eur J Clin Pharmacol. 2003; 59:429 - 42.

8. Parker AJ, Houston JB. Rate-limiting steps in hepatic drug clearance: comparison of hepatocellular uptake and metabolism with microsomal metabolism of saquinavir, nelfinavir and ritonavir. Drug Metab Dispos. 2008; 26: 1375 - 84.

9. Elsherbiny D. Pharmacokinetic drug-drug interactions in the management of malaria, HIV and tuberculosis. Acta Universitatis Upsaliensis Uppsala. 2008; 68:11 - 6 .

10. Handschin C, Meyer UA. Induction of drug metabolism: The role of nuclear receptors. Pharm Rev. 2003; 55: 649 - 73.

11. Perloff MD, von Moltke LL, Greenblatt DJ. Ritonavir and dexamethasone induce expression of CYP3A4 and P-glycoprotein in rats. Xenobiotica. 2004; 34:133 - 50.

12. Gonzales FJ, Coughtrie M, Tukey RH. Drug metabolism. In: Brunton LL, Parker KL. (eds). Goodman and Gilman's The Pharmacological Basis of Therapeutics. 12th ed. New York: Publ 2011. p. 123 - 43.

13. von Moltke, Durol ALB, Duan SX, Greenblatt DJ. Potent mechanism-based inhibition of human CYP3A in vitro by amprenavir and ritonavir: comparison with ketokonazole. Eur J Clin Pharmacol. 2000; 56: 259 - 61.

14. Lim YP, Kuo SC, Lai ML, Huang JD. Inhibition of CYP3A4 expression by ketokonazole is mediated by the disruption of pregnanc X receptor, steroid receptor coactivator-1, and hepatocyte nuclear factor 4 [alpha] interaction. Pharmacogenet Genomics. 2009; 19: $11-24$.

15. van Weert AW. Geuze HJ, Groothuis B, Stoorvogel W. Primaquine interferes with membrane recycling from endosomes to the plasma membrane through a direct interaction with endosomes which does not involve neutralisation of endosomal $\mathrm{pH}$ nor osmotic swelling of endosome. Eur J Cell Biol. 2000; 79: 394 - 9.

16. Hayesi R, Masimirembwa C, Mukanganyama S, Ungell ALB. The potential inhibitory effect of antiparasitic drugs and natural products on P-glycoprotein mediated efflux. Eur J Pharm Sci. 2006; 29: 70 - 81.

17. Ho RH, Kim RB. Transporters and drug therapy: Implications for drug disposition and disease. Clin Pharmacol Ther. 2005; 78: $260-77$.

18. Chen J, Raymond K. Roles of rifampicin in drug-drug interactions: underlying molecular mechanisms involving the nuclear pregnane $\mathrm{X}$ receptor. Ann Clin Microbiol Antimicrob. 2006; Feb 15;5:3.

19. Foisy MM. Induction effects of ritonavir: Implications for drug interactions. Ann Pharmacother. 2008; 42: 1048 - 59.

20. Kotegawa T, Laurijssens BE, von Moltke LL, Cotreau $\mathrm{MM}$, Perloff MD, Venkatakrishnan $\mathrm{K}$, et al. In vitro, pharmacokinetic and pharmacodynamic interactions of ketokonazole and midazolam in the rat. J Pharmacol Exp Ther. 2002; 302: $1228-37$. 